\title{
ACTIVITIES OF STUDY GROUP ON ZONAL TRAFFIC SYSTEM
}

\author{
地区交通分科会 \\ By Study Group on Zonal Traffic System
}

\section{1. 分科会発足の経緯と活動}

わが国においては，1960 年代から 70 年代にかけての 交通事故多発が「交通戦争」という言葉を生み出すなど, 安全性への取組みが活発となり，従来の広域幹線や都市 幹線交通に対する計画では処理しきれなかった地区の交 通計画の必要性が重要視されるようになった. その後, モータリゼーション偏重に対する反省から, 交通環境の 改善・人間性の回復, さらには歩車共存といった思想を 反映して，さまざまな試みが重ねられてきた。欧米での 新しい試みも紹介されるようになり, 学会レベルでも地 区交通に関する研究が多くみられるようになった.

このような背景の下，各地でそれぞれに特有のテーマ をもつた研究活動が進められ，その1つとして関西では 昭和 $60 \cdot 61$ 年度に土木学会関西支部共同研究グループ （代表：西村昂大阪市立大学教授）が編成され，翌 62 年度からは同じく地区交通計画研究委員会 (代表：西村 昂）が設置されるに至ってますます充実した取組みが行 われた.この成果は 2 年間の委員会活動の後, 地区交通 計画講習会（『よりよい地区の交通環境を目指して一そ の手法と事例』平成元年 7 月開催）で報告され，多くの 関係者から共感と反響を得ることができた。さらに，地 区交通の問題は各地域で特有の条件をもち, より広い視 野からのアプローチが必要であるとの認識に立ち, 昭和 63 年関係各位の支援もあって, 上木計画学研究委員会 に地区交通分科会が発足の運びとなった。

分科会は, 形式的には西村昂代表（大阪市立大学）と 各地域から選出された数名の幹事団とにより運営され， 過去 4 回の分科会では毎回 30 名以上の参加者によって それぞれ問題となっている課題が取り上げられてきた。
地区交通の課題は，上述のように多様な背景とともに 顕在化するものであり, そのため, 課題の抽出や分科会 活動の方向性に関しては, 分科会参加者へのアンケート 調査なども踏まえて議論が重ねられてきたところである. その最中, 土木計画学シンポジウム開催の機会を得るこ とになり，分科会としては多くの関係者への問いかけを 行い,さらにこれからの課題を明確化していく上でのス テップとしてシンポジウムを位置づけることとした．

\section{2. 第 23 回土木計画学シンポジウム一魅力あ} るみちづくり・まちづくり一の開催

シンポジウムの構成は, 分科会としての位置づけに 従って多くの事例を通じて新しい試みや問いかけ，さら には十分な議論が可能となるよう取りまとめられた。

シンポジウムは平成元年 11 月 $9 \cdot 10$ 日の両日中央大 学記念会館において開催され (写真一1), 分科会以外の 関連分野からも講師あるいはパネリストを迎え，幅広い

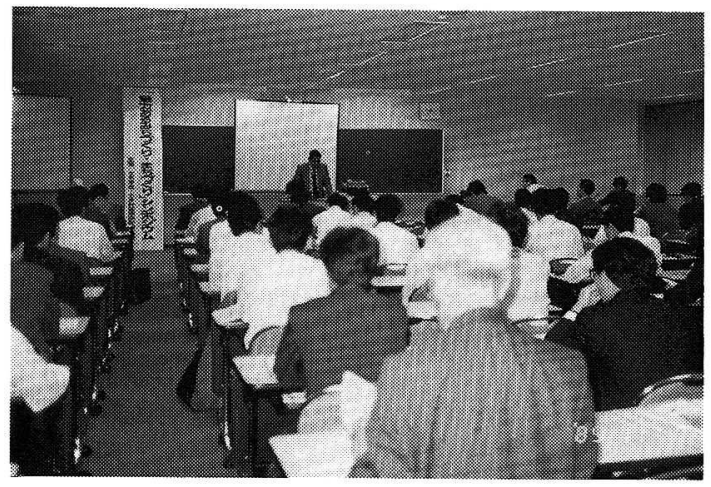

写真一1 シンポジウム風景 
視野からの話題提供と活発な議論が展開された.

シンポジウムの内容は，プログラム（表一1）からも 明らかなように 3 つのセッションとそれらに対する意見 交換およびパネルディスカッションで構成され，特に第 1 日目には住居系, 2 日目には都心商業業務系が主とし て取り上げられた.これは, 議論の明確化によって, 各 セッションに共通の議論の場を設け，しかもできるだけ 広い視野からの意見を得るための配慮であった。

以下には，各セッションの構成上の主旨（分科会とし て留意した点）について紹介しておく.

(1)セッション 1 : 地区交通の課題と計画＼cjkstart都市の規 模や地区の特性によって異なるさまざまな課題を整理す るとともに, 地区交通計画誕生の背景と歴史的変遷の中 で, 今後重要となるであろういくつかの課題を, 特に都 市交通・計画との関連, 最近の研究・事業の方向, 住民 参加論など幅広い視点で論述する.

(2)セッション 2 : 住区交通計画の潮流と課題住居 系地区での内外の最新事例を通じて, 面的アプローチ, 実験的アプローチ, 街路の演出と住民参加による管理手

\section{表一1 第 23 回土木計画学シンポジウム「魅力あるみちづくり・} まちづくり」プログラム

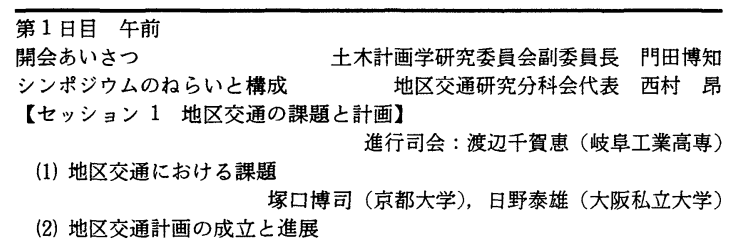

第 1 日目 午後

【セッション 2 地区交通の課題と計画】進行司会 : 高井広行（近畿大学） (1) 西ヨーロッパ諸国における住区内の面的交通抑制

(2) 街路の演出手法

(3) 住区交通抑制における実施上の課題

(4) 実験的アプローチを用いた交通改善の実践

(5) 住区内街路の管理と住民参加

【コメントおよび意見交換】

コメンテーター：西村 昂 (大阪私立大学), 榊原和彦 (大阪産業大学) 青木英明（軽量計画研究所）

第 2 日目 午前

【セッション 2 都心商業業務地区における交通計画】

(1) 駐車場案内システムと交通コントロール 栗本 譲 (名城大学)

（2）街路整備之商店街の活性化藤墳忠司（アーバンスタディ研究所）

（3）ウインターシティの街路環境設供堂柿栄輔 (北海道学園大学)

（4）歴史的観光都市の交通改善永井 護（宇都宮大学）

第 2 日目 午後

村田隆裕 (科学警察研究所)

(6) 都心商業業務地区における駐車問題之対応策高田邦道（日本大学）

(7) 都心ターミナル地区の計画一駅前広場の再生一

山川 仁（東京都立大学）

【パネルディスカッション みち・ひと・くるま そしてまちの顔づくり一魅 力ある都心空間の創造に向けて一】座 長 : 五十風日出夫 (北海道大学) パネリスト：新谷洋二 (東京大学), 鳴海邦碩 (大阪大学) 浅野光行（建設省建築研究所）千葉博正（北海道自動車短期大学） 土木計画学研究委員会副幹事長 中村良夫
法など，各種試みの実現性や効果について議論する.

(3) ッション 3 : 都心商業業務地区における地区交通 計画 都心地区で話題となることの多い, 駐車問題, 商業地区の活性化, 歩行者空間の整備, さらには歴史的 都市やウインター・シティあるいは都心夕ーミナルと いった特定の地区での課題とその取組みを議論する.

(4)意見交換とパネルディスカッション セッション 1,2 での話題提供の後, 個別テーマや地区交通計画全般 について，さまざまな立場のコメンテータ一からの意見 を用意し，今後の課題や方向性について検討する。また 2 日目のセッション 3 終了後には, 都市空間の創造と都 心地区における交通計画のあり方をテーマに，パネル形 式によりフロアーを交えた議論の場を用意する.

\section{3. シンポジウムの盛会と今後の活動}

シンポジウムには，地区交通の計画に携わるさまざま な分野から 200 名に上る参加者を得ることができた。

このことは，先に紹介した地区交通計画講習会（土木 学会関西支部) の盛会とも併せて, 地区交通問題への関 心の高さとそれに対応した計画への積極的な取組みの必 要性を改めて認識させるものであった。それと同時に， シンポジウム開催中, 話題提供者をはじめとする分科会 メンバーと参加者との間で具体的な意見交換がなされ， 今後の分科会での取組みへの要望とともにその成果に大 きな期待が寄せられた。こうした状況の中，シンポジウ 厶の開催は, 今後の地区交通計画の方向性を探るために 貴重な議論の場を提供し得たと思われる.

また，一方では本シンポジウムに先立って開催された 「高齿者・身障者のための都市・地域整備」研究分科会 (代表：五十嵐日出男北海道大学教授）による『活力あ る高齿化社会とまちづくり』講習会でも示されたように， 地区交通計画に密接にかかわる研究分野の活動も活発に 進んでいることから，分科会としては，今後このような さまざまな分野の方々との交流を通じて，魅力あるまち うくりの実現を目指したいと考えている.

(日野泰雄／Yasuo HINO: 大阪市立大学 土木工学科助手)

\section{参 考 文 献}

1) 土木計画学研究委員会：第 23 回土木計画学シンポジウム テキスト「魅力あるみちづくり・まちづくり」, 土木学会, 平成元年 11 月.

2) 地区交通計画研究委員会編 : 平成元年度講習会テキス 卜・地区交通計画（よりよい地区の交通環境を目指して 一その手法と事例), 土木学会関西支部, 平成元年 7 月.

3) 土木計画学研究委員会編：第 20 回土木計画学講習会テキ スト・活力ある高秢化社会とまちづくり, 土木学会, 平 成元年 9 月.

（1990.5.30・受付） 